\title{
Banded Net-Winged Beetle, Calopteron discrepans (Newman) (Insecta: Coleoptera: Lycidae) ${ }^{1}$
}

Donald W. Hall and Marc A. Branham²

\section{Introduction}

The banded net-winged beetle, Calopteron discrepans (Newman), is a colorful black and orange net-winged beetle commonly found resting on vegetation in moist woods throughout much of the eastern United States.

\section{Distribution}

Found in the eastern United States from New England south to Florida and west to Oklahoma and Kansas.

\section{Description}

Adults: The adults range in length from approximately 10 to $15 \mathrm{~mm}$. Males are smaller than females. The elytra have the elevated lengthwise ridges and cross ridges characteristic of most lycids and are orange with a median and a terminal black band.

The banding patterns of $C$. discrepans and the closely-related Calopteron reticulatum (Fabricius) are very similar in appearance. In C. discrepans, the 
a median band is present in $C$. terminale, it is not produced along the suture toward the bases of the elytra. Because of their similarity in appearance and variability of the banding patterns, the Calopteron species have often been misidentified.

Larvae: Larvae are black with burnt-orange patches.

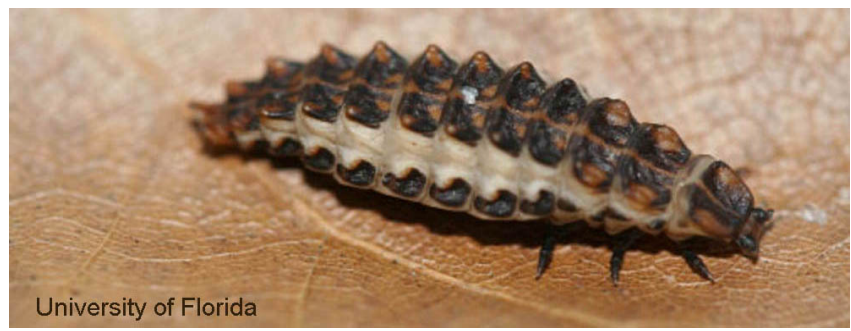

Figure 2. Calopteron discrepans (Newman) distended prepupal larva (dorsal view). Credits: D.W. Hall, University of Florida

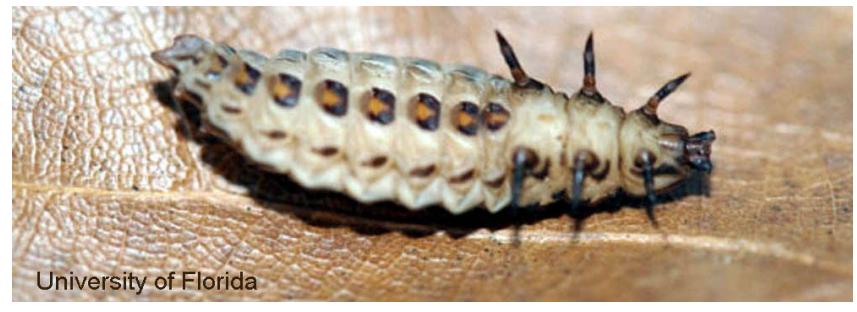

Figure 3. Calopteron discrepans (Newman) distended prepupal larva (ventral view). Credits: D.W. Hall, University of Florida

\section{Pupa:}

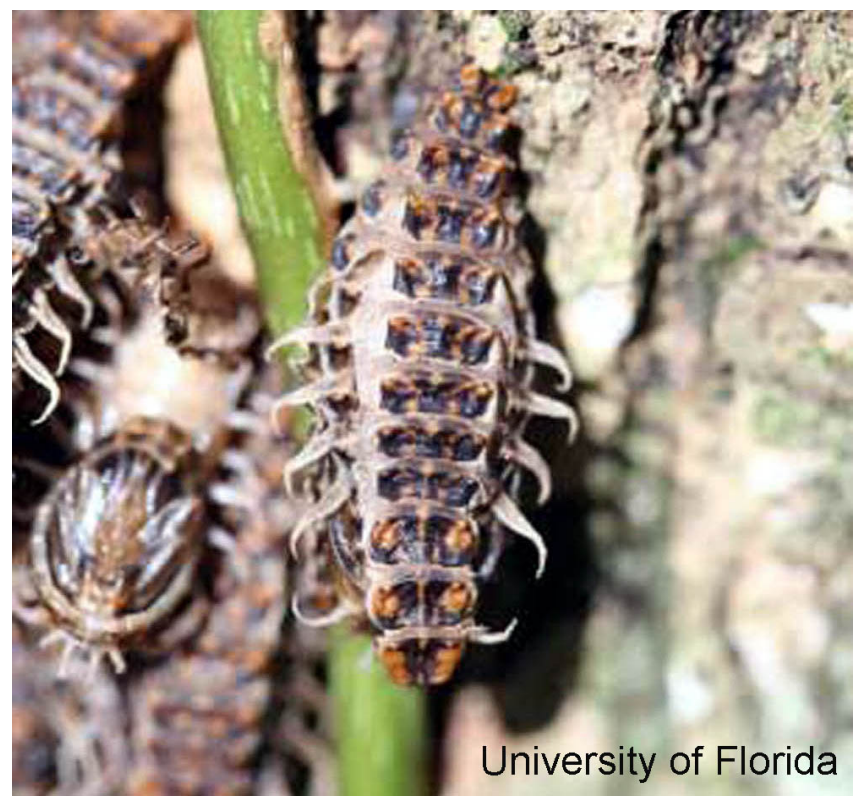

Figure 4. Calopteron discrepans (Newman) pupa within last instar larval pupal case. Credits: D.W. Hall, University of Florida

\section{Life Cycle and Biology}

Nothing is known of the egg stage and oviposition site of Calopteron species. Calopteron larvae are reported to live in rotten logs, under loose bark or, less commonly, in soil or leaf litter. Lycid larvae are reported to be predacious by some authors (Miller 1988, Triplehorn and Johnson 2005) whereas other authors (Lawrence 1991, Marshall 2006, McCabe and Johnson 1979, Withycombe 1926) report that they feed on myxomycetes, fungi, or fermenting plant juices.

Full-grown larvae of Calopteron species aggregate prior to pupation (McCabe and Johnson 1979, Moffat 1883, Withycombe 1926).

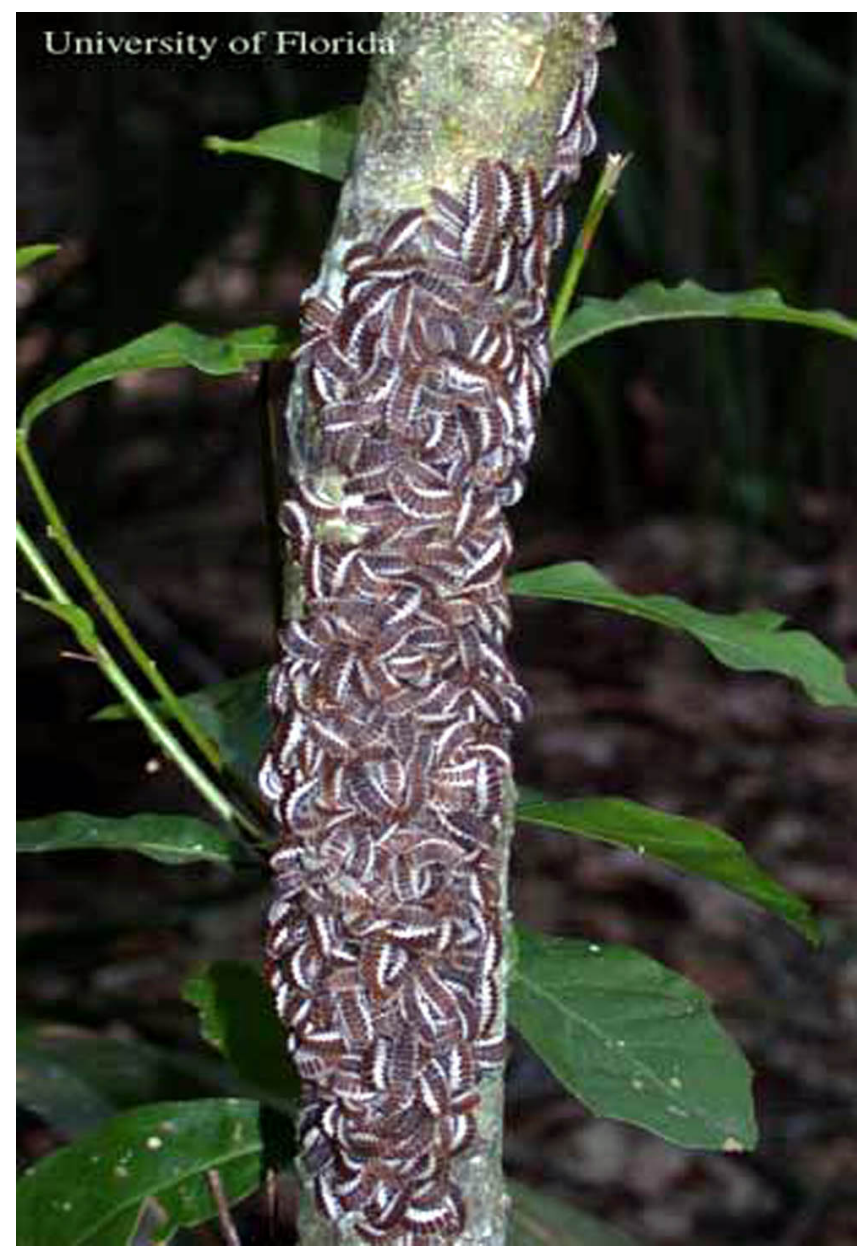

Figure 5. Prepupation aggregation of larvae of Calopteron sp. Credits: Lyle J. Buss, University of Florida

These aggregations may contain hundreds of pupae packed together in shingled masses. The $C$. discrepans aggregation pictured below is part of a larger aggregation that contained over 600 pupae. 


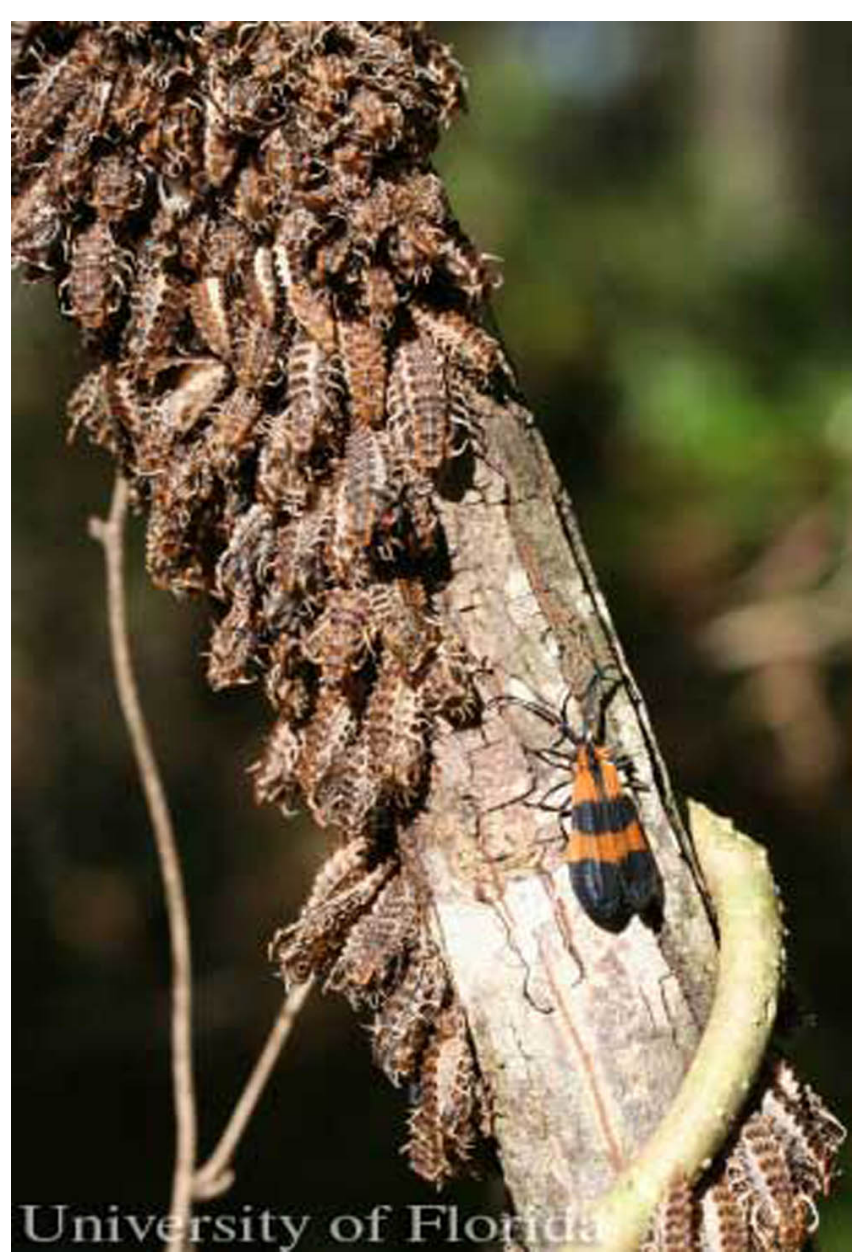

Figure 6. Calopteron discrepans (Newman) pupal aggregation and newly emerged adult. Credits: D.W. Hall, University of Florida

The colorful adults of $C$. reticulatum have been shown to contain pyrazines (that likely impart the repugnant scent of the beetles) and lycidic acid and other fatty acids that may render them distasteful to predators (Eisner et al. 2005), and other species of Calopteron are also likely distasteful. The integument of Calopteron larvae also displays bright, contrasting coloration, and the larvae are likely distasteful.

Pupation occurs within the last instar larval exoskeleton (Young and Fischer 1972). The exoskeletons which retain the bright larval coloration probably provide not only shelter but also aposematic (warning coloration) benefit to the pupae.

Aggregation of aposematic insects is generally believed to be adaptive as a defensive mechanism against predators (Riipi et al. 2001, Vulinec 1990), and that is the presumed benefit of the pre-pupation aggregation behavior of Calopteron.

\section{Selected References}

Dillon EA, Dillon LS. 1961. A Manual of Common Beetles of Eastern North America. Row, Peterson and Company. Evanston, Illinois. 884 pp.

Eisner T, Eisner M, Siegler M. 2005. Secret Weapons: Defenses of Insects, Spiders, Scorpions, and Other Many-Legged Creatures. Harvard University Press. Cambridge, Massachusetts. 384 pp.

Green JW. 1952. The Lycidae of the United States and Canada. IV. The tribe Calopterini (Coleoptera). Transactions of the American. Entomological Society (Philadelphia). 78: 1-19.

Lawrence JF. 1991. Lycidae (Cantharoidea), pp. 423-424. In Stehr FW. [editor] Immature Insects, Vol. 2. Kendall/Hunt Publishing Company. Dubuque, Iowa. $992 \mathrm{pp}$.

Marshall SA. 2006. Insects. Their Natural History and Diversity. Firefly Books. Buffalo, New York. 720 pp.

McCabe TL, Johnson LM. 1979. Larva of Calopteron terminale (Say) with additional notes on adult behavior (Coleoptera: Lycidae). Journal of the New York Entomological Society 87: 283-288.

Miller RS. 1988. Behavior of Calopteron reticulatum (F.) larvae (Coleoptera: Lycidae) Ohio Journal of Science 88: 119-120.

Moffat JA. 1883. Correspondence. Canadian Entomologist 15: 179-180.

Riipi MR, Alatolo RV, Lindström L, Mappes J. 2001. Multiple benefits of gregariousness cover detectibility costs in aposematic aggregations. Nature (London) 413 (6855): 512-514.

Triplehorn CA, Johnson NF. 2005. Borror and DeLong's Introduction to the Study of Insects. 7th edition. Thomson Brooks/Cole. Belmont, California. 864 pp.

Vulinec K. 1990. Collective security: aggregation by insects as a defense, pp. 251-288. In Evans DL, Schmidt JO. [editors] Insect Defenses: Adaptive Mechanisms and Strategies of Prey and 
Predators. State University of New York Press.

Albany, New York. 482 pp.

Withycombe CL. 1926.The biology of lycid

beetles in Trinidad. Proceedings of the

Entomological Society of London. 1: 32-33.

Young DK, Fischer RL. 1972. The Pupation of

Calopteron terminale (Say) (Coleoptera: Lycidae).

Coleopterists. Bulletin 26: 17-18. 